Arhe XVI, 31/2019

UDK 1 Thomas Aquinas

DOI https://doi.org/10.19090/arhe.2019.31.65-84

Originalni naučni rad

Original Scientific Article

\author{
GORAN RUJEVIĆ ${ }^{1}$ \\ Univerzitet u Novom Sadu, Filozofski fakultet
}

\title{
NOVA INTERPRETACIJA „TREĆEG PUTA” TOME AKVINSKOG
}

Sažetak: Toma Akvinski je poznat po svojih pet argumenata za dokazivanje postojanja Boga, a treći od tih ,pet puteva” jeste argument iz kontingentnosti koji ukazuje na nužnost postojanja nužnog bića. Ovaj „treći put” podvrgavamo argumentacionoj analizi koja razotkriva da postoje dve interpretacije ovog argumenta redukcije na apsurdnost. Interpretacija koja se zasniva na pronalaženju protivrečja sa iskustvenim činjenicama pokazuje se neadekvatnom usled toga što su njeni zaključci zasnovani na problematičnim opservacionim selekcionim efektima. Interpretacija koja se zasniva na pronalaženju protivrečja sa apriornim istinama pokazuje se nedovoljnom jer u sebi ne sadrži neophodnu apriornu građu. Kao rešenje ovih prigovora, predlažemo novu interpretaciju, gde se argument „trećeg puta” interpretira u kombinaciji sa argumentom „drugog puta”, koji onda može da pruži odgovarajući apriorni sadržaj spram kojeg se može uspostaviti odgovarajuća relacija protivrečnosti, a koji pri svemu tome neće zapadati u probleme sa posmatračkim selekcionim efektima. Predloženo rešenje podložno je daljoj evaluaciji i kritikovanju.

Ključne reči: Akvinski, antropičko rezonovanje, kontingentnost, kosmološki dokaz, reductio ad absurdum

\section{„TREĆI PUT” I NJEGOVI SRODNICI}

U moru mnogobrojnih pokušaja da ljudska bića svojim ograničenim intelektima dosegnu izvesnost postojanja apsolutno nadmoćnog Boga, klasično mesto pripada argumentima koji čine takozvanih „,pet puteva” koje je sabrao dominikanski monah Toma

\footnotetext{
${ }^{1}$ E-mail adresa autora: goran.rujevic@ff.uns.ac.rs
} 
Akvinski. Oni se mogu naći u njegovom delu Summa Theologiae ${ }^{2}$ (teološka suma), dok se nešto drugačija zbirka može naći u delu Summa contra Gentiles ${ }^{3}$ (suma protiv nevernika). Kada se govori o suvislosti ili upotrebnoj vrednosti ovih argumenata, često se ističe da njihova narav nije da budu konačni, rigorozni dokazi kao što bismo ih razumeli danas u logičkom smislu, već pre rekapitulacije ${ }^{4}$ i pregledi koji imaju potpornu ulogu demonstriranja racionalne osnove doktrine. ${ }^{5}$ Rečju, ovo ne bi bili dokazi za postojanje Boga, već pre dokazi $u$ prilog postojanja Boga. Edvard Feser [Edward Feser] to lepo iskazuje: „Ključno je razumeti da su [argumenti] sume. Akvinski nikada nije namerio da oni budu uzimani samostalno..."

Frederik Koplston [Frederick Copleston], istaknuti tomista, naglašava da je od pet argumenata koje Toma Akvinski navodi u Summa Theologiae, fundamentalan argument „trećeg puta”. ${ }^{7}$ Ovaj argument jeste pokušaj da se na osnovu pojmova kontingentnih i nužnih stvari dođe do zaključka da je nužno postojanje bar jedne nužne stvari - Boga. Upravo ovaj „treći put” će biti fokus našeg sadašnjeg interesovanja, u pokušaju da izvršimo argumentacionu analizu ovog postupka, iznesemo njegovu kritiku, te ponudimo način da se prigovori prevaziđu.

Argument Tome Akvinskog nije prvi slučaj pozivanja na uslovljenost kontingentnih stvari kao indikatora nužnog postojanja nužnog bića - Boga. Avicena je na više mesta u svom opusu

${ }^{2}$ Thomas Aquinas, The Summa Theologica. Part One, First Number, R. \& T. Washbourne Ltd, London 1911, str. 24-27.

${ }^{3}$ Thomas Aquinas, The Summa contra Gentiles. First Book, Burns, Oates \& Washbourne Ltd, London 1924, str. 23-33.

4 John I. Jenkins, Knowledge and Faith in Thomas Aquinas, Cambridge University Press, Cambridge 1997, str. 259.

${ }^{5}$ Frederick Copleston, Medieval Philosophy, Methuen \& Co. Ltd, London 1952, str. 90 .

${ }^{6}$ Edward Feser, Aquinas: A Beginner's Guide, Oneworld Publications, Oxford 2009, str. 62 (preveo G. R.).

${ }^{7}$ Frederick Copleston, A History of Philosophy. Volume II Medieval Philosophy, Doubleday, New York 1993, str. 345-346. 
upotrebljavao sličan argument, ${ }^{8}$ koji je u potpunosti bio metafizički utoliko što se nije oslanjao ni na kakvu iskustvenu spoznaju. ${ }^{9}$ Po svojoj strukturi, Avicenin dokaz je krajnje jednostavan: ono što postoji ili je nužno ili je kontingentno; ako je nužno, to je Bog; ako je kontingentno, ono zahteva da postoji nešto nužno, a to je stoga što svaka kontingentna stvar mora u pogledu svog postojanja da se osloni na kauzalni lanac koji završava nužnom stvari. ${ }^{10}$

Nešto drugačiji pristup sličnoj tematici iznosi i Majmonid. Na pomalo iznenađujući način, on u svetu ističe pojave koje su nasumične, nepravilne, haotične, te njihovo postojanje koristi kao demonstraciju za neophodnost postojanja božanskog plana. Uostalom, ove haotične pojave ne mogu biti proizvod slepe nužnosti, jer ona može da proizvodi samo uniformnost, dok Bog kao tvorac plana u svakom trenutku može taj plan da modifikuje i menja. ${ }^{11}$

Argument „trećeg puta” Tome Akvinskog gotovo da predstavlja sredinu između Avicenine i Majmonidove verzije. Sa jedne strane, ovaj argument apeluje na diskurzivnu racionalnu preciznost, dok sa druge strane vrlo jasno upotrebljava neke tipične fizikalističke kategorije. Ovom prilikom nećemo prenositi argument od reči do reči, već ćemo se usredsrediti samo na ključne iskaze koji formiraju njegovu srž:

„U prirodi stvari nalazimo da one mogu ili da postoje ili da ne postoje, jer nalazimo da nastaju i da propadaju [...] Nemoguće je da stvari uvek postoje [...] Ako sve može prestati da postoji, onda u jednom trenutku može biti da ništa ne postoji. [...] Ono što ne postoji nastaje samo putem nečega već postojećeg. Stoga, ako u jednom trenutku ništa nije postojalo, bilo bi nemoguće da išta nastane; tako čak ni sada ne bi ništa postojalo - što je apsurdno. Stoga, nisu sve stvari puko moguće,

\footnotetext{
${ }^{8}$ Michael E. Marmura, „Avicenna's Proof from Contingency for God's Existence in the Metaphysics of the Shifa"' u: Mediaeval Studies, Vol. XLII, Pontifical Institute of Mediaeval Studies, Toronto 1980, str. 337.

${ }^{9}$ Isto, str. 339.

${ }^{10}$ Isto, str. 340, 346.

${ }^{11}$ Moses Maimonides, The Guide for the Perplexed, E. P. Dutton \& Company, New York 1904, str. 184-189.
} 
već mora da postoji nešto čije je postojanje nužno. [...] Svi ljudi ovo nazivaju Bogom." 12

Stvari koje mogu da postoje ili da ne postoje ubuduće ćemo ukratko nazivati kontingentnim stvarima, stvarima koje nisu nužne. Prva stavka koju je značajno primetiti jeste da Toma Akvinski u ovom argumentu jasno mora da posegne za fizičkom kategorijom vremena, koju upotrebljava u onom trenutku kada postulira hipotetički slučaj koji uključuje beskonačno vreme ${ }^{13}$ a to je sadržano u odbijanju perpetualnog postojanja stvari. Ova upotreba fizičkih termina u okviru argumenta u korist postojanja Boga ne treba da čudi. Uostalom, započinjanje od i upućivanje na komponente saznanja koje potiču iz iskustva karakteristično je i za ostale „puteve” Tome Akvinskog. ${ }^{14}$ Druga bitna stavka jeste da se argument efektivno sastoji iz dva dela: u prvom delu (pre konstatacije apsurdnosti) se iznosi jedan hipotetički scenario koji služi za posredno dokazivanje, dok se u drugom delu (nakon konstatacije apsurdnosti) svode računi i preciziraju zaključci dobijeni na osnovu prvog dela. Mi ćemo našu pažnju usmeriti na taj prvi deo, za koji je inače prihvaćeno da je podložniji kritičkoj analizi. ${ }^{15}$

Ovu tvrdnju, zatim ranije pomenutu konstataciju da su argumenti „pet puteva” više pregledni argumenti nego iscrpni dokazi, kao i činjenicu da su ovi argumenti Tome Akvinskog izraženi krajnje šturo, u malo reči i sa mnogobrojnim otvorenim mestima, sve koristimo kao pokazatelje da je način interpretacije „trećeg puta” (i, zapravo, svakog od preostalih argumenata) zadatak koji je ostavljen kao otvoren svakom čitaocu dela Tome Akvinskog. Shodno tome, naša početna hipoteza u

12 Thomas Aquinas, The Summa Theologica. Part One, First Number, str. 26 (odabrao i preveo G. R.).

${ }^{13}$ Uporediti: Peter Kreeft, A Summa of the Summa, Ignatius Press, San Francisco 1990, str. 67.

${ }^{14}$ Leo J. Elders, The Philosophical Theology of St. Thomas Aquinas, E. J. Brill, Leiden 1990, str. 84.

15 John F. Wippel, The Metaphysical Thought of Thomas Aquinas: From Finite Being to Uncreated Being, The Catholic University of America Press, Washington D. C 2000, str. 468. 
ovom istraživanju jeste da su moguće višsestruke interpretacije argumenta „trećeg puta”, a nju ćemo najlakše ispitati ako podvrgnemo „treći put” argumentacionoj analizi. Te višestruke interpretacije onda ćemo podvrgnuti kritici, u nadi da ćemo moći ispostaviti jednu snažniju. Tom prilikom, trudićemo se da izbegnemo uobičajene prigovore protiv „trećeg puta" (na primer, da mogućnost nepostojanja ne podrazumeva aktualnost nepostojanja, ili da Akvinski vrši neprimereni pomak univerzalnog kvantifikatora $\mathrm{u}$ argumentu), jer smatramo da je na njih na drugim mestima dat adekvatan odgovor. ${ }^{16}$

\section{ANALIZA SAMOG ARGUMENTA - OSNOVI APSURDNOSTI}

Razmotrimo pobliže kakva je argumentaciona priroda prve polovine „trećeg puta" Tome Akvinskog. Kao i u slučaju preostalih puteva, ovde je reč o argumentu reductio ad absurdum, dovođenja uslovno prihvaćenih pretpostavki do apsurdnih zaključaka, čime se potkrepljuje teza neispravnosti tih uslovno prihvaćenih pretpostavki. Uslovna pretpostavka kojom Akvinski započinje svoj „treći put” jeste da su sve stvari na ovom svetu kontingentne, odnosno konverzno, da na ovom svetu nema nužnih stvari. Dovođenje te hipotetičke pozicije do izvesnog neprihvatljivog zaključka - apsurda - posredan je dokaz istinitosti kontradiktorne tvrdnje od uslovne pretpostavke; budući da uslovna pretpostavka beše „nijedna stvar na ovom svetu nije nužna”, njoj kontradiktoran je iskaz „postoji bar jedna nužna stvar na ovom svetu”, i za Tomu Akvinskog to jeste Bog.

Namerno smo u prethodnom odeljku naznačili da se dolazi do „izvesnog” neprihvatljivog zaključka, smerajući time na to da $\mathrm{u}$ argumentu Akvinskog možemo govoriti o više vrsta neprihvatljivosti zaključka, prvenstveno u pogledu porekla tvrdnje spram koje konačni zaključak biva apsurdan. U apstraktnim formalizovanim sistemima, reductio ad absurdum se naprosto oslanja na pronalaženje kontradikcije sa bilo kojim drugim prihvaćenim iskazom tog sistema, bez obzira na njegovo poreklo. Međutim, kao što smo već imali prilike da vidimo,

\footnotetext{
${ }^{16}$ Uporediti: Edward Feser, Aquinas: A Beginner's Guide, str. 90-99.
} 
„treći put” Tome Akvinskog nezaobilazno u sebe uključuje iskustveni sadržaj, samim tim, poreklo kontradikcije koja se uzima kao obeležje apsurda može biti višestruko - zasnovano na činjenicama iskustva, ili zasnovano na nužnim činjenicama razuma (da se provizorno poslužimo lajbnicovskom distinkcijom).

Smatramo da argument Akvinskog zadobija različite oblike s obzirom na to kakvo se poreklo kontradikcije može priložiti. Na osnovu postavljenih okvira, postoje dva načina po kojima za neki zaključak možemo reći da je apsurdan: 1) zaključak je kontradiktoran spram aktualne činjenice iskustva; 2) zaključak je kontradiktoran spram neke neiskustvene istine. Iskaz koji se u „trećem putu” identifikuje kao apsurdan jeste da „ništa ne postoji”; s obzirom na prethodnu distinkciju, možemo je proširiti na konkretan slučaj, te reći da postoje dve mogućnosti apsurdnosti zaključka na koje je Toma Akvinski mogao smerati svojim argumentom „trećeg puta”: 1) zaključak „ništa ne postoji” očigledno se kosi sa datim činjenicama; i 2) zaključak „ništa ne postoji” kosi se sa nužno prihvaćenim istinama.

Na prvi pogled, moglo bi se prigovoriti da su ove dve opcije u potpunosti identične, te da je njihovo razlikovanje redundantno. Takav prigovor bi bio zasnovan na naivnom prihvatanju da su sve iskustvene činjenice nužno prihvaćene istine (u suprotnom ne bismo mogli da se oslonimo na racionalnu argumentaciju). Ipak, tvrdimo da se jasna i sledstvena distinkcija ipak može održati utoliko što ne moraju sve nužno prihvaćene istine biti iskustvene činjenice. $\mathrm{U}$ ovom trenutku valjalo bi specifikovati početnu hipotezu ovog ispitivanja - naime, smatramo da različiti osnovi apsurdnosti podrazumevaju različite interpretacije argumenta, te da nemaju sve interpretacije jednaku argumentacionu snagu. Drugim rečima, različiti osnovi apsurdnosti prave značajnu razliku u pogledu suvislosti i valjanosti argumenta „trećeg puta”. Ta razlika, onda, opravdava povlačenje prethodno pomenute distinkcije, te je naš sledeći zadatak da je obrazložimo. Pošto razlika podrazumeva da su neke interpretacije argumenta ubedljivije od drugih, njeno artikulisanje ce ujedno biti i iznošenje prigovora na postojeće interpretacije, ali i otvaranje novog zadatka ovog istraživanja: demonstriranje mogućnosti još utemeljenije interpretacije. 


\section{INTERPRETACIJA POTPUNOG RASPADA}

Krenimo od prve opcije, da argument „trećeg puta” cilja na apsurdni zaključak koji se kosi sa iskustvenim činjenicama. Nazovimo tu opciju interpretacijom potpunog raspada (razlog za ovaj naziv postaće jasan uskoro). Provizorni zaključak Akvinskog da „ništa ne postoji” je, u tom slučaju, apsurdan usled toga što se jasno kosi sa činjenicama koje smo u stanju svakog trenutka da percipiramo: postoji bar nešto, postoji svet, postojimo mi u njemu, bar postoji naše poimanje tog sveta i naše trenutno razmišljanje o argumentima Akvinskog. Jasno je da svet još uvek postoji, da nije došlo do njegovog potpunog raspada, iako početna uslovna pretpostavka argumenta daje sasvim dovoljno vremena da se tako nešto dogodi - čitavu večnost. Razložno se može tvrditi da brojni interpretatori Tome Akvinskog (svakako oni koje smo u uvodnom odeljku ovog teksta pomenuli) stoje upravo na ovoj poziciji razumevanja „trećeg puta”.

Ali, ovde već možemo naslutiti prvi crv sumnje u legitimnost takvog zaključka. Činjenice iskustva lako su promenljive. To što stvari postoje sada ne garantuje nam da već kroz par sekundi neće nastupiti sveopšta kataklizma kao posledica kontingentnosti svega, što anulira pouzdanost čitavog argumenta „trećeg puta”. Toma Akvinski bi na to lako mogao odgovoriti - pretpostavljeno je beskonačno vreme, to je dovoljno vremena u kom bi se sveopšte propadanje moralo dogoditi. Ovaj odgovor, pak, uopšte nije toliko samorazumljiv koliko bi se na prvi pogled mogao činiti. Za ilustraciju toga, a ujedno i za artikulisanje prvog prigovora protiv interpretacije potpunog raspada, možemo se poslužiti jednim fizičkim fenomenom -vremenom poluraspada (spram kojeg smo ovoj interpretaciji dodelili ime).

Vreme poluraspada je stabilna karakteristika materijala kojom se opisuje vreme koje je potrebno da se njegova količina smanji na polovinu od početne usled radioaktivnog raspada atoma tog materijala. Iako se taj parametar tehnički može iskazati za svaki mogući oblik tvari, on se praktično ne upotrebljava u slučaju stabilnih supstanci (čija su vremena poluraspada nezamislivo dugačka), već se uglavnom koristi za opisivanje supstanci koje su sačinjene od nestabilnih, rekli bismo radioaktivnih, 
atoma. Vreme poluraspada je inherentno probabilistički koncept zato što je radioaktivni raspad od kojeg zavisi propadanje materijala nasumičan i na nivou pojedinačnog atoma krajnje nepredvidljiv događaj. Gledano u malom, u pogledu samih atoma, vreme poluraspada je probabilistička mera, kojom se izražava da je verovatnoća da će neki pojedinačan atom pretrpeti radioaktivni raspad $\mathrm{u}$ datom vremenu tačno $50 \%$. Posmatrano $\mathrm{u}$ velikom, zahvaljujući zakonu velikih brojeva, vreme poluraspada je statistička mera koja izražava vreme koje je potrebno da prosečno polovina atoma pretrpi radioaktivni raspad. Što je broj atoma o kojima je reč veći, to je vreme poluraspada konkluzivnija mera. Ali, to ujedno znači da je radioaktivni raspad eksponencijalni proces, to jest, da zavisi od raspoložive količine materijala. $\mathrm{Na}$ osnovu toga, nakon dva vremena poluraspada, ne očekuje se da će materijal u celini iščeznuti, već da će preostati četvrtina od početne količine. Konačni raspad i poslednjeg preostalog atoma ne može se pouzdano predvideti, samim tim ne možemo da govorimo o pouzdanom vremenu potpunog raspada.

Relevantnost ovog fizičkog koncepta za argument „trećeg puta” Tome Akvinskog oslanja se na ideju da je probabilistička priroda radioaktivnog raspada adekvatna aproksimacija za propadljivost kontingentnih stvari. Jednako kao što za pojedinačne atome ne možemo tačno znati kada će pretrpeti radioaktivni raspad, tako ni za kontingentne stvari verovatno ne možemo definitivno znati kada će propasti, već možemo samo očekivati da će se to u nekom trenutku doista desiti. Štaviše, možemo reći da je slučaj sa kontingentnim stvarima još dramatičniji, jer njihova raznolikost ne može da jemči ni da će u proseku zavladati zakon velikih brojeva, kao što je slučaj sa zbirom atoma istog materijala.

Naravno, Toma Akvinski na svom teoretskom raspolaganju ima čitavu beskonačnost, tako da nemogućnost artikulisanja tačnog vremena potpunog raspada ni na koji način ne utiče na validnost argumenta. Značaj povlačenja paralele sa vremenom poluraspada leži u tome što se iz ovog upoređivanja može vrlo efikasno uočiti da je hipotetičko stanje u kom ništa ne postoji (to stanje potpunog raspada/propadanja) konačno demarkirano jednim individualnim događajem - propadanjem poslednje kontingentne stvari na svetu. Taj individualni događaj inherentno je 
probabilistički (pojedinačna stvar je po usvojenoj pretpostavci kontingentna). Beskonačno vreme nam tehnički garantuje izvesnost tog događaja, ali ne pošteđuje ni nas ni Tomu Akvinskog od polaganja računa o načinu kako je taj probabilistički događaj razumljen. Naime, nasumični događaji i tumačenja verovatnoće ljudima su notorno teški za poimanje, i često i najdisciplinovaniji umovi imaju poteškoće da pomire formalne i intuitivne parametre. Intuitivno nam događaj propadanja poslednje kontingentne stvari na ovom svetu ima smisla, razumemo šta pojedinačne reči u toj sintagmi znače i čini nam se da ih razumemo uzete zajedno. Ali, da li smo u stanju da ispostavimo formalne parametre tog događaja, tačnije, pod kojim uslovima hipotetički posmatrač može sa pouzdanjem da kaže da je posvedočio tom događaju? Drugim rečima, da li je iskaz „ništa ne postoji” suvisao?

Odgovor na ovo pitanje podrazumeva izlaženje iz okvira argumenta „trećeg puta” kako ga je zacrtao Toma Akvinski, i zapravo predstavlja srž naše kritike, za sada usmerenu samo protiv njegove interpretacije potpunog raspada. Akvinski, naime, nije ni u jednom trenutku obrazložio subjektivne determinante hipotetičkog stanja potpunog raspada. Uostalom, zašto bi? Njegov zadatak nije bio da ponudi doslednu rekonstrukciju propalog sveta, već da pokaže nepodudarnost takvog sveta sa proverljivim stanjem stvari. S obzirom na to, rekonstrukcija subjektivnih determinanti izgleda izlišna, jer Akvinski računa na aktualno postojeće racionalne subjekte koji pred sobom imaju i čitaju Summa Theologiae. Nažalost, ovo je pogreška koju su u istoriji ljudske misli počinile mnoge pametne glave, a metodološko proučavanje te problematike doživelo je svoj uspon tek u proteklih nekoliko decenija $\mathrm{u}$ obliku istraživanja „spoznajnih pristrasnosti”. Neke od tih pristrasnosti tiču se upravo problematike intuitivnog razumevanja verovatnoće.

$\mathrm{U}$ savremenoj nauci, antropičkim rezonovanjem se ukratko naziva širok skup metodoloških i kritičkih razmatranja koja su usmerena na rasvetljavanje takozvanih posmatračkih selekcionih efekata, odnosno sistemskih grešaka u naučnom rezonovanju koje proističu iz izvesnih nereflektovanih subjektivističkih determinacija predmeta proučavanja. Drugim rečima, posmatrački selekcioni efekat obuhvata artefakte koji u predmetu posmatranja proizvodi perspektiva posmatrača, kao što $u$ 
tipičnom primeru gustina mreže diktira koja je najmanja vrsta ribe koja će se naći u slučajnom ulovu. Najpoznatiji slučaj antropičkog rezonovanja jesu Karterova [Brandon Carter] antropička načela, koja principijelno tvrde da je „ono što ćemo posmatrati određeno uslovima neophodnim za postojanje nas posmatrača"17.

Karterova antropička načela opterećena su mnogobrojnim interpretativnim teškoćama (neke verzije su prazne tautologije, neke sadrže prećutane pretpostavke), i mi se ovog puta nećemo poslužiti njima, već ćemo posegnuti za alternativom koju je predložio Nik Bostrom [Nick Bostrom], za takozvanom snažnom pretpostavkom samouzorkovanja. Ova pretpostavka je jednostavno metodološko načelo koje kaže: „Treba rezonovati tako kao da je trenutni trenutak posmatranja nasumični uzorak iz skupa svih trenutaka posmatranja svoje referentne klase" ${ }^{\text {"18 }}$. Nešto drugačije izrečeno, nemamo razloga da mislimo da je bilo koji pojedinačni trenutak posmatranja i po čemu privilegovaniji od nekog drugog i svaki pojedinačni trenutak posmatranja determinisan je onim uslovima pod kojim stoji skup svih trenutaka posmatranja odgovarajuće vrste.

Ako primenimo ove principe antropičkog rezonovanja na interpretaciju potpunog raspada, uvidećemo da je demonstrirana činjenička kontradikcija zapravo rezultat subjektivne determinisanosti posmatranih činjenica, a ne apsurdnosti uslovnih pretpostavki. Naime, subjekti, odnosno posmatrači, koji treba da konstatuju nepodudarnost između zaključka „ništa ne postoji” i činjeničkog stanja koje posmatraju i sami su deo tog sveta kontingentnih stvari. Jedini mogući trenuci posmatranja su trenuci u kojima bar neke kontingentne stvari postoje; $u$ onom momentu kada kontingentni svet pretrpi potpuni raspad, to propadanje uključuje i moguće posmatrače, stoga neće biti nikog ko bi

${ }^{17}$ Brandon Carter, „Large Number Coincidences and Anthropic Principle in Cosmology" u: Confrontation of Cosmological Theories with Observational Data; Proceedings from the Symposium, D. Reidel Publishing Co, Dordrecht 1974, str. 291 (preveo G. R.).

${ }^{18}$ Nick Bostrom, Anthropic Bias, Routledge, New York 2004, str. 162 (preveo G. R.). 
bio u stanju da verifikuje problematični zaključak o nepostojanju ničega. Drugim rečima, Toma Akvinski nije uzeo u obzir da, bez obzira na to što beskonačno vreme garantuje da će sve kontingentne stvari u jednom trenutku propasti, i u tom beskonačnom vremenu skup mogućih trenutaka posmatranja ograničen je na onaj period kada nešto postoji. U tom okviru, tvrdnja „ništa ne postoji” nije apsurdna, samo je neizreciva za bilo kog posmatrača. Tomistički zaključak iz interpretacije potpunog raspada je, samim tim, artefakt posmatračkog selekcionog efekta, a ne objektivna i pouzdana karakteristika sveta. Interpretacija potpunog raspada u tome se pokazuje metodološki nevaljanom.

\section{INTERPRETACIJA KATEGORIČKE APSURDNOSTI}

Pređimo sada na ispitivanje druge naznačene interpretacije „trećeg puta" Tome Akvinskog. Ova interpretacija temelji se na obrazloženju da je osnov apsurdnosti tvrdnje „ništa ne postoji” njeno košenje sa nekom neiskustvenom, a priori prihvaćenom činjenicom. Usled toga, ovu interpretaciju ukratko ćemo nazivati interpretacijom kategoričke apsurdnosti, jer ona konačno smera na to da pokaže kako je apsurdnost hipotetičkog zaključka nezavisna od bilo kakvih pojedinačnih uslova, rečju, da se kategorički protivi racionalnim principima.

S obzirom na to, interpretacija kategoričke apsurdnosti veoma elegantno zaobilazi sve prigovore koje smo na prethodnim stranicama izneli protiv interpretacije potpunog raspada. Budući da interpretacija kategoričke apsurdnosti ne zahteva nikakvu konkretnu činjenicu niti konkretno iskustvo spram koje bi zaključci argumenta bili kontradiktorni, ona time ne zahteva ni postojanje konkretnog spoznajnog subjekta koji bi bio $\mathrm{u}$ posedu neke iskustvene činjenice. Dabome, interpretacija kategoričke apsurdnosti i dalje pretpostavlja postojanje izvesnog subjekta, racionalnog subjekta koji je u posedu izvesnih apriornih istina, ali takav subjekat se u potpunosti može smatrati idealizovanim racionalnim sagovornikom koji nema potrebe da izlazi iz okvira svog pretpostavljenog znanja (kantijanski rečeno, radi samo sa apriornim sudovima), te samim tim, ne podleže pod uslove antropičkog rezonovanja 
niti snažne pretpostavke samouzorkovanja. Uostalom, idealizovani racionalni sagovornik minimalna je pretpostavka svakog argumenta.

Drugim rečima iskazano, ova interpretacija razrešava temporalistički izazov koji je inherentan argumentu „trećeg puta” time što apeluje na vanvremeno stanovište za argument koji se oslanja na hipostaziranje beskonačnog perioda vremena. U tom pogledu, moglo bi se čak i tvrditi da je interpretacija kategoričke apsurdnosti utoliko bezuslovnija, te čak i približnija argumentativnom duhu Tome Akvinskog, ako se o tako nečemu uopšte može suditi.

Ipak, ova prednost u pogledu prethodne kritike vrlo lako postaje mana i slabost same interpretacije kategoričke apsurdnosti. Više se ne možemo osloniti na to da se traži direktna kontradikcija sa zaključkom „ništa ne postoji”, jer, kao što smo već videli, takva tvrdnja (,,postoji bar jedna stvar") jasno zahteva iskustvenu činjenicu kao osnov. Neophodno je ili pronaći neku dalju implikaciju zaključka „ništa ne postoji”, ili eksplicirati takav okvir nužnih uslova koji je inherentno kontradiktoran, a koji je indikovan pomenutom tvrdnjom. Kako stvari sada stoje, nema ničeg inherentno kontradiktornog $\mathrm{u}$ ideji da jedan svet kontingentnih entiteta mirno postoji i onda, polako, tokom beskonačno dugo vremena, troši se, gubi i nestaje. Nema čak ničeg kontradiktornog zamisliti da je to sudbina upravo ovog sveta u kom aktualno obitavamo, jer, sasvim u Hjumovom duhu obrazloženja, njegovo postojanje danas nije nikakav garant da će nastaviti tako da opstoji i sutra, pa čak ni za sat vremena.

Naprosto, za potrebe interpretacije kategoričke apsurdnosti, argument „trećeg puta”, ako se uzme sam po sebi, nije sadržajno dovoljno bogat da bi obezbedio smislenu i apriornu kontradikciju, odnosno apsurd. No, za razliku od interpretacije potpunog raspada, čiji je argumentacioni problem bio nerešiv, interpretacija kategoričke apsurdnosti može se očuvati ukoliko se u sam argument unesu dodatni postulati i odredbe. Već je u prethodnom pasusu naznačeno kakav okvir ti dodatni postulati moraju da sačine. Naša je namera, stoga, da se vodimo tim naznakama, te da pokušamo pronaći jedan novi interpretativni model $\mathrm{u}$ kom argument „trećeg puta” Tome Akvinskog može da se smatra kao dosledan i celovit. Taj novi model će, efektivno, biti podvrsta interpretacije kategoričke apsurdnosti, tačnije, oslanjaće se na mogućnost iznalaženja apriorne 
kontradiktornosti, a od ,izvorne” interpretacije će se razlikovati po tome što će argument biti obogaćen sa nekoliko novih presupozicija. Naravno, trudićemo se da sve nove presupozicije budu minimalne po broju i saglasne sa opšteprihvaćenom doktrinom Tome Akvinskog - uostalom, vredi podsetiti na već citirane Feserove reči, argumenti Tome Akvinskog nisu uobličeni da bi se razmatrali u izolaciji.

\section{NOV MODEL INTERPRETACIJE}

Formiranje novog modela započećemo tako što ćemo razmotriti jedan prigovor protiv argumenta ,trećeg puta” koji nismo načinili usled njegove očigledne neispravnosti. Naime, neki beskrupulozni filozofkritizer mogao je da pokuša da pokaže kako Toma Akvinski zapada ili u nedoslednosti ili u cirkularnost svojom upotrebom argumenata ,pet puteva". Rezon za to bi bio jednostavan: Toma Akvinski, sa jedne strane, temeljno prihvata hrišćansku ideju stvorenog i propadljivog sveta, čiji je konačni usud definitivno zacrtan u perspektivi božanskog plana; sa druge strane, on $\mathrm{u}$ argumentu ,trećeg puta" hipostazira jedan svet kontingentnosti, svet čija propast nije konačni stadijum nikakvog velikog plana i iza kojeg ostaje samo muka tišina slučajnosti, ako uopšte ima smisla govoriti o tome da išta ostaje iza takvog sveta. Nije li podrazumevano da će ovakva dva viđenja sveta konačno u nekom trenutku doći u stanje uzajamnog protivrečenja? Drugim rečima, zar u argumentu „trećeg puta” Toma Akvinski ne namešta sebi igru unapred utoliko što namerno bira scenario sa kojim se doktrinarno neće složiti, to jest, čini prestup cirkularnog rezonovanja time što je unapred pretpostavio zaključak do kojeg navodno pokušava da dođe?

Lako je ukazati zašto ovaj beskrupulozni prigovor nema utemeljenje. On, naime, u celosti promašuje argumentativni sentiment postupka reductio ad absurdum, a onda se tendenciozno poziva na najnepovoljnije obrazloženje te isfabrikovane situacije. Odbrana se jednostavno uspostavlja time što se ukazuje na činjenicu da Akvinski upotrebljava argumente svih ,pet puteva" uz ideju da smo u stanju da predstavimo hipotetičke situacije koje bi bile utemeljene samo na onim parametrima koji su u „putevima” propisani, a zaključci se tek post 
festum koriste kao (posredna) obrazloženja alternativnog viđenja. Toma Akvinski, takoreći, stavlja doktrinu Tvorevine u zagrade prilikom analiziranja kontraprimera.

Neuspeh ovog nečuvenog prigovora za nas ipak ima korisne posledice. Iz njegovog neadekvatnog dometa gotovo da možemo izmeriti koji je prihvatljivi obim „novog” ili „spoljašnjeg” sadržaja koji se može koristiti za bogaćenje argumenta „trećeg puta”. Uključivanje elemenata šire hrišćanske doktrine, videli smo, nije prihvatljivo, jer se time devalvira sam argument. Zapravo, uključivanje bilo čega izvan sadržaja koji je prisutan u ,pet puteva" rizikuje da kontaminira racionalni argument neopravdanim presupozicijama. Ne preostaje nam ništa drugo nego da dodatni sadržaj potražimo unutar preostalih ,puteva”, pri čemu se još dodatno možemo ograničiti samo na one ,puteve” koji prethode „trećem putu”.

Inspirisani Aviceninim pristupom argumentu iz kontingentnosti, usredsredimo se na „drugi put" koji se oslanja na razmatranje neophodnosti adekvatnog eficijentnog uzroka. ${ }^{19}$ Celokupan argument jeste usmeren na zaključak o postojanju Boga tvorca kao vrhovnog eficijentnog uzroka, ali on se može posmatrati i kao argument u korist nužnog postojanja lanca eficijentnih uzroka, tačnije, ideje da na svetu ne može postojati neka stvar a da nema uzrok svog postojanja u nečemu drugom izvan sebe. Ovaj zaključak argumenta „drugog puta” sada možemo da dodamo sadržaju argumenta „trećeg puta”. Ukoliko uslovna pretpostavka „trećeg puta” može nekako da dovede do tome kontradiktorne tvrdnje (,postoji stvar koja nema svog uzroka”), time bismo dobili kategoričku apsurdnost ,trećeg puta” u odnosu na već utvrđene zaključke „drugog puta”.

Izazov je, sada, kako dovesti hipotezu o svetu kontingentnih stvari u vezu sa tvrdnjom o postojanju neuzrokovane stvari, i još da sve to bude suvislo obuhvaćeno postojećim obrazloženjem koje nudi Toma Akvinski. Osnovni problem tiče se same pozicije univerzalne (ne)uzrokovanosti - govorimo o metafizičkoj karakteristici koju, samim tim, $u$ racionalnom ispitivanju nije teško po potrebi uslovno pretpostaviti

${ }^{19}$ Thomas Aquinas, The Summa Theologica. Part One, First Number, str. 25-26. 
ili uslovno eliminisati, već je stvar u tome kako artikulisati konkluzivan dokaz koji će tu pretpostavku učiniti relevantnom i konsekventnom. Ovde, konačno, dolazimo do našeg novog predloga $u$ interpretaciji „trećeg puta” Tome Akvinskog. Naime, smatramo da se ovaj argument može postaviti tako da jedna specifična ali nužna posledica koja proizilazi iz početnih parametara izvrši funkciju probnog kamena za hipotezu univerzalne (ne)uzrokovanosti.

Pre svega, započinjemo od prihvatanja zaključaka „drugog puta”, to jest od tvrdnje da ,ne postoje stvari koje nemaju uzrok izvan sebe”. Potom, prihvatamo uslovne pretpostavke „trećeg puta” koje glase da „nijedna stvar na svetu nije nužna” i „svet postoji beskonačno dugo”. Kontingentnost stvari razumevamo jednako kako je Toma Akvinski napomenuo da se razume, kao karakteristiku da stvari mogu da ne budu. Drugim rečima, kontingentnost se efektivno odražava time što što stvari mogu spontano da propadaju.

$\mathrm{U}$ ovom trenutku dodajemo novu odredbu uz ovo shvatanje kontingentnosti, za koju smatramo da ni najmanje ne krši početnu ideju: kontingentne stvari jednako mogu spontano da nastaju. U ovom trenutku, oštroumni čitaoci mogli bi uzviknuti da je ova spontana generacija upravo stvar koja se protivi prihvaćenom zaključku „drugog puta”, to jest, da ovde tendenciozno pretpostavljamo ono što želimo da dokažemo. Ključno opravdanje za ovu pretpostavku, međutim, krije se u nemogućnosti njenog inicijalnog dokazivanja: naime, haotičan svet kontingentnih stvari u kojem stvari nestaju po svojoj kontingenciji a nastaju po eficijentnom uzroku drugih stvari i haotičan svet kontingentnih stvari koje i nestaju i nastaju po svojoj kontingenciji lako mogu biti uzajamno nerazlučivi ukoliko je to kontingentno nastajanje tako usaglašeno (rekli bismo prestabilirano) da se ne razlikuje od efekata eficijentne uzročnosti. Dabome, verovatnoća za tako nešto jeste mala, ali da podsetimo, mi tražimo kategorički, a ne probabilistički dokaz.

Sada dodajemo drugu novu odredbu u argument ,trećeg puta”. Uobičajeno je shvatanje da se stadijum potpune propalosti stvari shvata kao svojevrsni „kraj sveta”, ništavilo nakon prethodne beskonačne punine. Međutim, zahvaljujući dodatku mogućnosti spontane generacije, ta punina vrlo lako može da se proširi i na drugu stranu trenutka ništavila. 
$\mathrm{U}$ tom slučaju, stanje u kojem su sve kontingentne stvari propale nije neko konačno stanje, već samo jedno od mogućih stanja u kome se svet pod parametrima kontingentnog propadanja i nastajanja stvari može naći. Štaviše, budući da govorimo o svetu koji beskonačno traje, sasvim je izvesno da će se u istoriji tog sveta naći bar jedan trenutak, ma koliko kratak, u kom su sve kontingentne stvari bile u stanju nepostojanja. Nazovimo taj trenutak prelomnim trenutkom.

Smatramo da je tek sa tim prelomnim trenutkom moguće imati konkluzivan dokaz o tome da su pogaženi zaključci „drugog puta”. Prelomni trenutak, naime, predstavlja drastičan prekid u kontinuitetu i punini hipostaziranog kontingentnog sveta i neposredna je demonstracija toga da je lanac eficijentnih uzroka nepostojeći utoliko što sam prelomni trenutak predstavlja definitivan prekid mogućnosti tog lanca. Strožim rečnikom rečeno, prelomni trenutak je nesumnjiva demonstracija da neke stvari - konkretno, prva stvar koja spontano nastane nakon prelomnog trenutka - mogu da nastanu bez eficijentnog uzroka. U formalnom pogledu, to je definitivan dokaz tvrdnje da ,postoji stvar koja nema svog uzroka”, a ona je u jasnoj kontradikciji sa zaključkom „drugog puta”. Na taj način, kategorička apsurdnost „trećeg puta” oslanja se na nužnu i apriornu kontradikciju sa zaključkom „drugog puta”.

Ova interpretacija sasvim je usaglašena sa argumentativnim isticanjima koje navodi Toma Akvinski. Nemogućnost da ni iz čega nastane nešto, to jest, neprihvatljiva ideja da se $\mathrm{u}$ hipostaziranom scenariju sveta nužno mora naći prelomni trenutak nepostojanja jasna je indikacija apsurdnosti zaključaka koji proističu iz uslovnih pretpostavki „trećeg puta”. Pored toga, ova obogaćena interpretacija zaobilazi prigovor subjektivističke determinisanosti utoliko što se u potpunosti oslanja na apriorne i hipotetičke tvrdnje, bez pozivanja na konkretne činjenice ili bilo kakvo stanovište sa kojeg se te činjenice imaju ustanoviti. Najzad, jedini element argumenta koji ima ikakve veze sa verovatnoćom jeste tvrdnja da se u beskonačnom vremenu mora dogoditi prelomni trenutak, koja je po sebi kategorička i valjana, te ne nosi opasnost od ikakvog pristrasnog razumevanja verovatnoće. Ovu novu i, verujemo, poboljšanu interpretaciju argumenta ,trećeg puta” Tome 
Akvinskog nazivamo obogaćenom interpretacijom kategoričke
apsurdnosti.

\section{ZAKLJUČAK}

$\mathrm{Na}$ prethodnim stranicama smo demonstrirali kako različiti osnovi apsurdnosti na koje se argument „trećeg puta” oslanja mogu imati jasne posledice na formiranje doslednih interpretacija tog argumenta. Izneli smo nekoliko prigovora koji su u pitanje doveli interpretaciju koja se oslanja na činjeničnu kontradikciju, kao i nekoliko zapažanja koji su pokazali da apriorna kontradikcija nije u potpunosti izvesna. Potom smo, služeći se naznakama koje su utvrđene tokom ispitivanja predložili dopunu interpretaciji koja se oslanja na apriorističku kontradikciju kako bismo ispostavili takvo shvatanje argumenta koje uspešno odgovara na izazove koji su u prethodnoj analizi ustanovljeni.

Vredi napomenuti da su u ovom postupku od krucijalne važnosti bile izvesne ideje koje su znatno mlađe od argumenta ,trećeg puta” Tome Akvinskog. Koncepcija vremena poluraspada, antropičko rezonovanje, kao i snažna pretpostavka samouzorkovanja su sve ideje koje potiču iz savremene nauke i naučne metodologije. Na mogući prigovor da je upotreba ovakvih koncepcija anahronistička i nepravedna prema Tomi Akvinskom koji ih, izvesno, nije mogao imati na raspolaganju, odgovaramo da smatramo da je za bilo kakvu analizu argumentacije koju sprovodimo u sadašnjosti sasvim opravdano upotrebljavati sav konceptualni aparat koji nam je pri ruci. Drugim rečima, ne vidimo saznajnu vrednost simuliranja istorijskih okolnosti u istraživanju koje nije istorijsko, već se tiče argumentacione strukture. Uostalom, verujemo da ni sam Toma Akvinski ne bi imao ništa protiv ideje da se ljudsko saznanje osvežava novim elementima, budući da je i sam u svojoj misli morao da balansira između ideja prolaznih i ideja večnih saznanja. Nešto slično konstatuje i Popovićeva, istina u drugačijem kontekstu filozofije Tome Akvinskog, kada kaže: „Međutim, izbor istih tih prolaznih dobara ne mora biti grešan ukoliko je vođen sub specie aeternitatis, odnosno ukoliko je ono konačno i prolazno sagledano s obzirom na perspektivu apsolutnog, unutar kojeg sopstvo koje je preuzelo na sebe odnos sa 
Bogom vidi i sebe samo." ${ }^{20} \mathrm{U}$ pogledu razmatranja valjanosti argumenta, njegova bezvremena ispravnost bi bila njegova apsolutna vrednost, a partikularna znanja koja tu ispravnost potkrepljuju bi bile ti konačni i prolazni elementi.

Takođe, u okviru ovog filozofskog eksperimenta, naša namera nikada nije bila da Tomi Akvinskom spočitamo da je nova interpretacija koju mi nudimo baš ona koju je Akvinski imao na umu kada je artikulisao argument „trećeg puta”. Prvo, tako nešto je krajnje malo verovatno. Načelo jednostavnosti nam sugeriše da je Akvinski na umu verovatno imao interpretaciju koja se oslanjala na kontradiktornost sa činjenicama, jer je za bilo koju drugu interpretaciju neophodno mnogo više diskurzivne obrazloženosti da bi se smatrala dovoljno objašnjenom. A da ne pominjemo da je potrebno imati posebnu vrstu filozofske bezobzirnosti da se tvrdi kako smo tek sada, posle više od pola milenijuma, napokon došli u posed one jedne prave interpretacije. Drugo, nekakva potraga za intencijom autora od pre toliko stotina godina po sebi je izlišan posao. Toma Akvinski se u toliko različitih pogleda s pravom smatra za jednog od istaknutih učenjaka zapadne misli da gotovo možemo reći da mu dugujemo da za svaki argument koji je on ponudio pronađemo što bolju i povoljniju interpretaciju, bez obzira na to na šta je on tačno smerao kada je sačinio original.

Naposletku, nova interpretacija koju smo ponudili ne mora da se uzima za definitivan i nepokolebljiv pristup ovom argumentu. Niti smatramo da smo ovom interpretacijom pružili nepobitan dokaz postojanja Boga. Postoje još mnogobrojni drugi aspekti sa kojih se čitav poduhvat ,pet puteva" može kritikovati, i njihov raspon se kreće od vrlo načelnih do sasvim konkretnih. Na primer, jedan od izvesnih formalnih prigovora koji se može uputiti „trećem putu”, a koji mi nismo razmotrili u okviru ovog ispitivanja jeste da li je opravdano da se postupak reductio ad absurdum vrši uz dve uslovne pretpostavke (pretpostavka o univerzalnoj kontingentnosti i pretpostavka o beskonačnom trajanju

\footnotetext{
${ }^{20}$ Una Popović, „Lenjost kao ukidanje čoveštva. Toma Akvinski o grehu lenjosti i vrlini ljubavi" u: Lenjost (priredili Dragan Prole i Alpar Lošonc), Adresa, Novi Sad 2016, str. 76-77.
} 
sveta). Očigledan odgovor koji se nudi, da su te dve propozicije inherentno povezane i nekako impliciraju jedna drugu, nipošto se ne sme prihvatiti kao podrazumevan i zahteva ozbiljnu analizu u budućnosti. Do tada, ipak smatramo da je veoma bitno da pred sobom uvek imamo najsnažnije interpretacije argumenata koje kritikujemo, jer to za sobom povlači zahtev za jednako snažnom kritikom. U tome vidimo korist predložene obogaćene interpretacije kategoričke apsurdnosti.

\section{LITERATURA}

Aquinas, Thomas, The Summa contra Gentiles. First Book, Burns, Oates \& Washbourne Ltd, London, 1924.

Aquinas, Thomas, The Summa Theologica. Part One, First Number, R. \& T. Washbourne Ltd, London, 1911.

Bostrom, Nick, Anthropic Bias, Routledge, New York, 2004.

Carter, Brandon, „Large Number Coincidences and Anthropic Principle in Cosmology" u: Confrontation of Cosmological Theories with Observational Data; Proceedings from the Symposium, D. Reidel Publishing Co, Dordrecht, 1974, str. 291-298.

Copleston, Frederick, A History of Philosophy. Volume II Medieval Philosophy, Doubleday, New York, 1993.

Copleston, Frederick, Medieval Philosophy, Methuen \& Co. Ltd, London, 1952.

Elders, Leo J, The Philosophical Theology of St. Thomas Aquinas, E. J. Brill, Leiden, 1990.

Feser, Edward, Aquinas: A Beginner's Guide, Oneworld Publications, Oxford, 2009.

Jenkins, John I, Knowledge and Faith in Thomas Aquinas, Cambridge University Press, Cambridge, 1997.

Kreeft, Peter, A Summa of the Summa, Ignatius Press, San Francisco, 1990.

Maimonides, Moses, The Guide for the Perplexed, E. P. Dutton \& Company, New York, 1904.

Marmura, Michael E, „Avicenna's Proof from Contingency for God's Existence in the Metaphysics of the Shifa"' u: Mediaeval Studies, Vol. XLII, Pontifical Institute of Mediaeval Studies, Toronto, 1980, str. 337-352.

Popović, Una, „Lenjost kao ukidanje čoveštva. Toma Akvinski o grehu lenjosti i vrlini ljubavi" u: Lenjost (priredili Dragan Prole i Alpar Lošonc), Adresa, Novi Sad, 2016, str. 45-87. 
Wippel, John F, The Metaphysical Thought of Thomas Aquinas: From Finite Being to Uncreated Being, The Catholic University of America Press, Washington D. C, 2000.

\author{
GORAN RUJEVIĆ \\ University of Novi Sad, Faculty of Philosophy
}

\title{
A NEW INTERPRETATION OF AQUINAS' "THIRD WAY"
}

\begin{abstract}
Thomas Aquinas is known for his five arguments for God's existence, and of these "Five Ways", the third one is known as the argument from contingency, wherein the necessity of a necessary being is demonstrated. We submit this "Third Way" to argumentational analysis, which uncovers the existence of two distinct interpretations of this argument of reduction to absurdity. The interpretation based on finding a contradiction with experiential facts is shown as inadequate due to having its conclusions based on problematic observation selection effects. The interpretation based on finding a contradiction with a priori truths is shown as insufficient, as it does not posess the required a priori content. As a solution to these objections, we propose a new interpretation, one where the "Third Way" argument is regarded in conjunction with the "Second Way" argument, which then supplies the required a priori content needed for establishing a contradiction, all the while avoiding the pitfalls of observation selection effects. The proposed solution can be subjected to further evaluation and critique.
\end{abstract}

Keywords: anthropic reasoning, Aquinas, contingency, cosmological proof, reductio ad absurdum

Primljeno: 21.2.2019.

Prihvaćeno: 9.5.2019. 